Muir, G., A. J. Lowe, C. C. Fleming and C. Vogl (2004): High nuclear genetic diversity, high levels of outcrossing and low differentiation among remnant populations of Quercus petraea at the margin of its range in Ireland. Ann. Bot. 93, 691-697.

NARUM, S. R., M. BANKS, T. D. BeAcham, M. R. BEllinger, M. R. Campbell, J. Dekoning, A. Elz, C. M. Guthrie, C. Kozfkay, K. M. Miller, P. Moran, R. Phillips, L. W. Seeb, C. T. Smith, K. Warheit, S. F. Young and J. C. GARZA (2008): Differentiating salmon populations at broad and fine geographical scales with microsatellites and single nucleotide polymorphisms. Mol. Ecol. 17, 3464-3477.

OGDEN, R. (2008): Fisheries forensics: the use of DNA tools for improving compliance, traceability and enforcement in the fishing industry. Fish and Fisheries 9, 462-472.

Orru, L., G. Catillo, F. Napolitano, G. De Matteis, M. C. ScATA, F. Signorelli and B. Moioli (2009): Characterization of a SNPs panel for meat traceability in six cattle breeds. Food Control 20, 856-860.

Piry, S., A. Alapetite, J. M. Cornuet, D. Paetkau, L. BAudouin and A. Estoup (2004): GENECLASS2: A software for genetic assignment and first-generation migrant detection. J. Hered. 95, 536-539.
Rannala, B. and J. L. Mountain (1997): Detecting immigration by using multilocus genotypes. Proc. Natl. Acad. Sci. U.S.A. 94, 9197-9201.

Steinkellner, H., S. Fluch, E. TuretscheK, C. Lexer, R. Streiff, A. Kremer, K. Burg and J. Glössl (1997): Identification and characterization of $(\mathrm{GA} / \mathrm{CT})$ microsatellite loci from Quercus petraea. Plant Mol. Biol. 33, 1093-1096.

Wasser, S. K., C. Mailand, R. Booth, B. Mutayoba, E. Kisamo, B. Clark and M. Stephens (2007): Using DNA to track the origin of the largest ivory seizure since the 1989 trade ban. Proc. Natl. Acad. Sci. U.S.A. 104, 4228-4233.

Wasser, S. K., A. M. Shedlock, K. Comstock, E. A. Ostrander, B. Mutayoba and M. Stephens (2004): Assigning African elephant DNA to geographic region of origin: Applications to the ivory trade. Proc. Natl. Acad. Sci. U.S.A. 101, 14847-14852.

WeIR, B. S. (1990): Genetic Data Analysis. Sinauer Associates, Sunderland, MA.

Xing, J. C., W. S. Watkins, D. J. Witherspoon, Y. H. Zhang, S. L. Guthery, R. Thara, B. J. Mowry, K. Bulayeva, R. B. Weiss and L. B. Jorde (2009): Finescaled human genetic structure revealed by SNP microarrays. Genome Research 19, 815-825.

\title{
Population Structure and Molecular Characterization of Nigerian Field Genebank Collections of Cacao, Theobroma cacao L.
}

\author{
By P. O. AiKPoKPodion 1),2),4),*), M. KolesniKova-ALLen ${ }^{2)}$, V. O. AdeTIMIRIN ${ }^{3)}$,

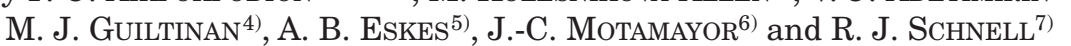

(Received $2^{\text {nd }}$ October 2008)

\begin{abstract}
Inadequate knowledge of the population structure and diversity present often hamper the efficient use of germplasm collections. Using a high through-put system, twelve microsatellite loci were used to analyze genetic diversity and population structure in a national

1) Plant Breeding Division, Cocoa Research Institute of Nigeria PMB 5244 Ibadan Nigeria.

2) Central Biotechnology Laboratory, International Institute of Tropical Agriculture PMB 5320 Ibadan Nigeria.

3) Department of Agronomy, University of Ibadan, Nigeria.

4) Department of Horticulture, 422 Life Sciences Building, Pennsylvania State University, University Park, PA 16802, USA.

5) Bioversity International, Parc Scientifique Agropolis II, 34397 Montpellier Cedex 5, France.

$\left.{ }^{6}\right)$ Mars Incorporated, Subtropical Horticulture Research Station, USDA-ARS, 13601 Old Cutler Road, FL33158.

7) Subtropical Horticulture Research Station, USDA/ARS, 13601 Old Cutler Road, FL33158.

*) Corresponding author's current address: Department of Genetics and Biotechnology, University of Calabar, PMB 1115, Calabar, Cross River State, Nigeria. E-Mail: paikpokpodion@ yahoo.com
\end{abstract}

field genebank repository of 243 cacao accessions grouped into 11 populations based on their known sources. Based on multi-locus profiles, the Bayesian method was used for individual assignment to verify membership in each population, determine mislabeling and ancestry of some important accessions used in breeding program. A total of 218 alleles was revealed with a mean number of 18.2 alleles per locus. Gene diversity $\left(H_{e}=0.70\right)$ and allelic richness (4.34 alleles per locus) were highest in the $\mathrm{F}_{1}$ hybrid population. Differential mating system was suggested as responsible for the observed deficit and excess of heterozygotes observed among the populations. Analysis of molecular variance showed that within-population variance accounted for $63.0 \%$ of the total variance while the rest $37 \%$ was accounted for by the among-population variance. Cluster dendrogram based on UPGMA revealed two main subsets. The first group was made up of the Amelonado/Trinitario ancestry and the other of Nanay/Parinari ancestry. We found that Nanay and Parinari populations were the major source of Upper Amazon genes utilized while a large proportion of genetic diversity in the field genebank remained under-utilized in development of improved cultivars released to 
farmers in Nigeria. This study showed that the presence of alleles of the Upper Amazon Forasteros (Nanay, Parinari and Iquitos Mixed Calabacillo) genetic materials in the locally available accessions predated the formal large scale introduction of Upper Amazon materials in 1944. This is the first report of population structure of field genebank collections of cacao in Nigeria since more than seven decades of formal cacao breeding research.

Key words: cacao, fixation index, germplasm, cultivars, gene diversity, Hardy-Weinberg equilibrium.

\section{Introduction}

Cacao, Theobroma cacao, a diploid fruit tree species $(2 \mathrm{n}=20)$ originally designated a member of the Sterculiaceae family (PURSEGLOVE, 1974), but recently re-classified into the Malvaceae (ALVERSon et al., 1999) is native to the humid tropical regions of the northern parts of South America, and the northern parts of Central America (CheEsman, 1944; CuATRECASAS, 1964). However, since introduction in the late $19^{\text {th }}$ century, the West and Central African region has become the largest producer accounting for more than $70 \%$ of the world's cocoa output of 3.592 million metric tons (ICCO, 2008). Dried cocoa beans obtained from the cacao tree are the main products used in the chocolate and confectioneries industries worth an estimated US $\$ 70$ billion annually in the United States alone and exports from producing countries worth US $\$ 5-6$ billion annually (GUILTINAN, 2007). In Africa, cocoa production is predominantly a smallholders' enterprise with several hundred-thousand families depending on this cash crop for their livelihood and significant foreign exchange earnings for producing countries (Rice and GreEnBerg, 2000, Motamayor et al., 2008). Nigeria currently ranks fourth globally among cocoa producers, and in comparison with other agricultural commodities, cocoa makes the largest non-oil contribution to the nation's economic development and accounted for $65 \%$ of total agricultural export in 2004 (AikPOKPODION, 2007).

Since the first introduction of cacao into Nigeria in 1874, when Squiss Ibaningo transported pods of 'Amelonado' cocoa from Fernando Po, there has been a series of additional germplasm introductions as reviewed by (BARTLEY, 2005; AIKPOKPODION, 2007). However, formal selection programs and germplasm conservation started around 1931 by O.J. VOELCKLER at the Nigerian Department of Agriculture in Moor Plantation, Ibadan by the Colonial Administration. Further germplasm introductions of some Trinitario and Criollo selections from Trinidad and Ceylon, respectively, were made in 1933 (JACOBS et al., 1971). Several materials belonging to Upper Amazon Forastero and Trinitario populations were also introduced from Trinidad by the West African Cocoa Research Institute (WACRI) into Tafo, Ghana in 1944 (Toxopeus, 1964). In the mid-1960's, large scale introductions sponsored by the Cocoa Alliance of London was initiated in Nigeria which consisted of 313 clones and 701 seedling progenies derived from some 350 intra-Nanay, intra-Parinari, intra-Iquitos and inter$\mathrm{P}$ (Pound's selections) crosses. Cocoa germplasm materials were also introduced from Costa Rica, Indonesia, Fernando Po, Kew Gardens (United Kingdom),
Wageningen (The Netherlands) and Miami (USA) (JACOBS et al., 1971; OlATOYE and EsAN, 1992). Although several hundred clones and accessions are now existing in the Nigerian field collection, there has been no study on the genetic diversity of this collection as is the case with many cacao germplasm collections worldwide (ZhANG et al., 2006a, Zhang et al., 2009; Motilal et al., 2009, Johnson et al., 2009, MotAmAyor et al., 2008).

A rational and efficient use of available germplasm collection depends largely on the knowledge of the nature and amount of genetic diversity present in the collections as well as the relationships among various accessions. This knowledge can also guide in the formulation of appropriate breeding strategies for the development of improved planting materials and integration of useful diversity into the breeding program. Considering the current climate variability, disease pressure, land pressure due to increasing population and urbanization that makes less land available for new plantings, increasing cost of production due to increased labour wages, old age of farms and farmers, the use of improved germplasm for new plantings and rehabilitation of old plantations becomes imperative. This requires a judicious and an optimum use of available genetic resources to develop well-adapted improved cultivars.

The use of molecular markers provides the most efficient means of assessing the extent of genetic diversity in germplasm collections. An international consortium of scientists in academic centers and government sponsored laboratories involved in the cocoa industry have agreed to the use of a set of standardized simple sequence repeat (SSR) primers for characterizing cacao germplasm collections (SAUNDERS, 2004, ZHANG et al., 2006a). The SSR marker system developed in cacao (LANAUD et al., 1999) has played significant role in increasing our understanding of the genetic structure and diversity in cacao germplasm (LANAUD et al., 2001; SERENO et al., 2006; ZHANG et al., 2006b; AIKPOKPODION et al., 2009), clone identification (CRYER et al., 2006, SAUNDERS et al., 2004) identification of mislabelled clones (ZHANG et al., 2006a), parentage analysis (SCHNELL et al., 2005) and of the origin and dispersal of cacao (MotamaYor et al., 2002, 2003, 2008).

In view of the growing interdependence of all cocoagrowing countries for testing and utilization of cacao genetic resources, which makes the characterization of these resources a matter of global importance, we used microsatellite markers to investigate the genetic diversity of field genebank collections in Nigeria. This information will be useful to determine how much of the global cacao genetic resources are represented in this collection, to what extent these have been used to develop varieties released to farmers and how to exploit useful germplasm for development of improved varieties in future breeding programs.

\section{Materials and Methods}

\section{Plant materials and sample collection}

Leaf samples used for generating DNA fingerprinting profiles were taken from trees of 243 cacao clones and accessions in field genebank locations of the Cocoa 
Table 1. - Field genebank accessions assigned to their 'Self' and 'Other' population by Bayesian clustering method.

\begin{tabular}{lccccc}
\hline Population & $\begin{array}{c}\text { No. } \\
\text { genotyped } \\
\text { accessions }\end{array}$ & $\begin{array}{c}\text { No. } \\
\text { correctly } \\
\text { assigned }\end{array}$ & $\begin{array}{c}\text { Other } \\
\text { population }\end{array}$ & $\begin{array}{c}\text { \% Error } \\
\text { rate }\end{array}$ & $\begin{array}{c}\text { No. } \\
\text { verified } \\
\text { identity }\end{array}$ \\
& & & & & \\
\hline IMC & 7 & 7 & 0 & 0 & 13 \\
NA & 10 & 8 & 2 & 20.0 & 20 \\
PA & 10 & 8 & 2 & 20.0 & 17 \\
SCA & 6 & 6 & 0 & 0 & 10 \\
Amelonado & 7 & 7 & 0 & 0 & 22 \\
Trinitario & 10 & 9 & 1 & 10.0 & 29 \\
Local Selection & 14 & 5 & 9 & 64.3 & 15 \\
F Hybrid & 104 & 28 & 76 & 73.1 & 28 \\
F Hybrid & 20 & 19 & 1 & 5.0 & 41 \\
GB Selections & 48 & 22 & 26 & 54.2 & 22 \\
GBTRDI & 14 & 10 & 4 & 28.6 & 17 \\
Total & 250 & 129 & 121 & 46.4 & 234 \\
& & & & & \\
\hline
\end{tabular}

Research Institute of Nigeria (CRIN) headquarters, Ibadan $\left(07.02^{\circ} \mathrm{N}, 03.09^{\circ} \mathrm{E} ; 122 \mathrm{~m}\right.$ above sea level <asl>) and her four sub-stations in Owena, Ondo State $\left(07.20^{\circ} \mathrm{N}, 05.03^{\circ} \mathrm{E} ; 263 \mathrm{~m}\right.$ asl), Uhonmora, Edo State $\left(06.81^{\circ} \mathrm{N}, 06.02^{\circ} \mathrm{E} ; 160 \mathrm{~m}\right.$ asl), Ibeku, Abia State $\left(05.54^{\circ} \mathrm{N}, 07.58^{\circ} \mathrm{E} ; 82 \mathrm{~m}\right.$ asl) and Ajassor, Cross River State $\left(05.88^{\circ} \mathrm{N}, 08.82^{\circ} \mathrm{E} ; 140 \mathrm{~m}\right.$ asl $)$. These were classified into 11 main groups.

1. Local Selections ('LOCAL') collected from the local population of West Africa cacao landraces available in the country at the inception of cocoa research in the early 1930s by earlier workers (LockWOOD and GWAMFI, 1979). These were coded in the genebank collection as C-clones (C1-C38). This population is a mixture of both local Amelonado (green pods) and local Trinitario (red pods).

2. Trinitario materials ('TRINITARIO') are Imperial College Selections ('ICS') clones obtained from Trinidad and have been used as parents in some crosses made available to farmers as planting materials.

3. Amelonado ('AMEL') population representing the Bahian Amelonado introduced by the Portuguese to Sao Tome and Principe which formed the base population first cultivated in West Africa.

4. Parinari ('PA') population,

5. Nanay ('NA') population,

6. Iquitos Mixed Calabacillo ('IMC') population

7. Scavina ('SCA') population.

The PA, NA, IMC and SCA populations are the main Upper Amazon Forastero progenitors of the introduced germplasm from Trinidad in the early 1940s, that became the basis of Amazon cocoa released in all West African countries breeding programmes.

8. $\mathrm{F}_{1}$-Hybrid clones (' $\mathrm{F}_{1}$-HYB') are the first generation progenies derived from crosses among Upper Amazon clones as well as their crosses with other populations such as Trinitario, introduced from Trinidad to West African Cocoa Research Institute (WACRI) Headquarters in Tafo (now Cocoa Research Institute of Ghana) and its Ibadan substation (now CRIN) in 1944 (Pos-
NETTE and TODD, 1951). These were the clones principally used as parents in various national breeding programmes to develop hybrid selections distributed to farmers such as the WACRI Series I \& II selections in Ghana and Nigeria, These hybrids were coded ' $T$ ' and ' $C$ ' clones.

9. $\mathrm{F}_{2}$-Hybrid progenies (' $\mathrm{F}_{2}$-HYB') were developed from either open-pollinated or controlled crosses of various $\mathrm{F}_{1}$-clones. These have been used to develop the $\mathrm{F}_{3}$-Amazon 'Synthetic' cultivar distributed to farmers in Nigeria.

10. Genebank Selections ('GB-S') are progenies in the genebank derived from several crosses including double cross and adaptability hybrids derived from the 1967 Intra-Nanay and Intra-Parinari crosses, open-pollinated derived crosses from Catongo Blanc and 'Adaptability Hybrids' involving crosses of Introduced Upper Amazon crosses with local Amelonado.

11. 1967 Trinidad Introduction ('GB-TRD') materials are bi-parental hybrid progenies of intra-Nanay and intra-Parinari clones introduced into Nigeria in 1967 (ATANDA, 1975).

\section{DNA extraction, Polymerase chain reaction (PCR) and Electrophoresis}

Extraction of total genomic DNA from recently fully expanded leaves about two months old was performed following the procedure outlined by BHATTACHARJEE et al. (2004), DNA concentration was adjusted to 2.5 ng. $\mu \mathrm{L}^{-1}$. Twelve microsatellite markers previously reported (LANAUD et al., 1999) were used in this study. PCR amplification reactions were performed in a MJ research PTC 200 thermal cycler (MJ Research, Watertown, Mass) with $5 \mu \mathrm{L}$ total volume, containing $0.5 \mu \mathrm{L}$ of cacao DNA ( 2.5 ng. $\left.\mu \mathrm{L}^{-1}\right)$. All PCR reactions contained $0.5 \mu \mathrm{L}$ of $10 \mathrm{X}$ PCR buffer (10 mM Tris-HCl pH 8.3, $50 \mathrm{mM} \mathrm{KCl}), 0.5 \mu \mathrm{L}$ of $25 \mathrm{mM} \mathrm{MgCl}_{2}, 0.125 \mu \mathrm{L}$ each of forward and reverse primer $(10 \mathrm{mM}), 0.1 \mu \mathrm{L}$ of $10 \mathrm{mM}$ dNTPs), 0.05 U. $\mu \mathrm{L}^{-1}$ of Taq polymerase (Bioline). The thermal cycling profile consisted of the following: $4 \mathrm{~min}$ denaturation at $94{ }^{\circ} \mathrm{C}$; followed by 32 repeats of the fol- 
lowing cycle: $94^{\circ} \mathrm{C}$ for $30 \mathrm{~s}, 1 \mathrm{~min}$ at $46^{\circ} \mathrm{C}$ or $51^{\circ} \mathrm{C}$ annealing temperature depending on primer, $1 \mathrm{~min}$ extension at $72^{\circ} \mathrm{C}$, with a final $7 \mathrm{~min} 72^{\circ} \mathrm{C}$ extension. Capillary electrophoresis (CE) was performed on ABI PRISM $^{\circledR} 3100$ Genetic Analyzer (Applied Biosystems) in a $36 \mathrm{~cm}$ capillary array using POP 4 (Applied Biosystems) as previously described by AIKPOKPODION et al. (2009). Resulting data were analyzed with GeneMapper $^{\mathrm{TM}}$ software version 3.5 (Applied Biosystems) for internal standard and fragment size determination.

Table 2. - Bayesian clustering analysis (PRITCHARD et al., 2000) of Local Selection population indicating probability of membership in group ( $-=$ less than 0.05 level of probability).

\begin{tabular}{|c|c|c|c|c|c|}
\hline \multirow[t]{2}{*}{ Clone } & \multicolumn{5}{|c|}{ Probability of membership } \\
\hline & NA & PA & IMC & Amelonado & TRINITARIO \\
\hline C13 & - & - & - & 0.240 & 0.731 \\
\hline C14 & - & - & - & - & 0.922 \\
\hline $\mathrm{C} 16$ & - & - & - & 0.299 & 0.673 \\
\hline C17 & - & - & - & 0.964 & - \\
\hline C19 & 0.604 & 0.308 & - & - & - \\
\hline $\mathrm{C} 20$ & - & - & 0.482 & 0.139 & 0.336 \\
\hline $\mathrm{C} 21$ & - & - & - & 0.964 & - \\
\hline $\mathrm{C} 22$ & 0.554 & 0.372 & - & - & - \\
\hline $\mathrm{C} 23$ & - & - & - & 0.671 & 0.301 \\
\hline $\mathrm{C} 24$ & - & - & - & 0.283 & 0.692 \\
\hline $\mathrm{C} 25$ & - & - & - & 0.707 & 0.265 \\
\hline $\mathrm{C} 26$ & - & - & - & 0.926 & - \\
\hline $\mathrm{C} 27$ & 0.602 & 0.361 & - & - & - \\
\hline N38 & - & - & - & 0.962 & - \\
\hline
\end{tabular}

Table 3. - Summary statistics of 12 microsatellite markers used in field genebank accessions of cacao in Nigeria.

\begin{tabular}{|c|c|c|c|c|c|c|c|c|c|}
\hline Marker & LG & $H_{e}$ & $H_{o}$ & $P I C$ & $K$ & $F_{i s}$ & $F_{i t}$ & $F_{s t}$ & $H W E$ \\
\hline$m T c C I R I$ & 4 & 0.863 & 0.722 & 0.847 & 19 & -0.077 & 0.162 & 0.222 & 0.001 \\
\hline$m T c C I R 1$ & 1 & 0.894 & 0.807 & 0.882 & 17 & -0.033 & 0.115 & 0.144 & 0.000 \\
\hline$m T c C I R 1$ & 4 & 0.556 & 0.560 & 0.537 & 14 & -0.070 & 0.167 & 0.222 & $0.125^{\mathrm{NS}}$ \\
\hline$m T c C I R I$ & 4 & 0.820 & 0.748 & 0.800 & 24 & -0.149 & 0.123 & 0.237 & $0.099^{\mathrm{NS}}$ \\
\hline$m T c C I R I$ & 2 & 0.805 & 0.652 & 0.785 & 17 & -0.031 & 0.236 & 0.260 & 0.000 \\
\hline$m T_{c} C I R 2$ & 3 & 0.788 & 0.760 & 0.773 & 23 & -0.128 & 0.032 & 0.143 & $0.792^{\mathrm{NS}}$ \\
\hline$m T c C I R 2$ & 9 & 0.512 & 0.536 & 0.497 & 18 & -0.066 & 0.134 & 0.191 & 0.042 \\
\hline$m T c C I R 2$ & 6 & 0.841 & 0.767 & 0.823 & 17 & -0.194 & 0.099 & 0.245 & 0.006 \\
\hline mTcCIR26 & 8 & 0.782 & 0.772 & 0.751 & 14 & -0.124 & 0.076 & 0.178 & $0.326^{\mathrm{NS}}$ \\
\hline$m T c C I R 3$ & 2 & 0.903 & 0.789 & 0.892 & 23 & -0.098 & 0.127 & 0.203 & 0.000 \\
\hline$m T c C I R 6$ & 6 & 0.777 & 0.726 & 0.747 & 15 & -0.156 & 0.127 & 0.245 & 0.011 \\
\hline$m T c C I R 9$ & 6 & 0.739 & 0.642 & 0.715 & 17 & -0.066 & 0.178 & 0.230 & 0.000 \\
\hline \multicolumn{10}{|c|}{ Mean over loci } \\
\hline \multirow{2}{*}{\multicolumn{2}{|c|}{$\begin{array}{l}\text { Jackknifing over all loci } \\
\text { (mean } \pm \text { std. deviation) } \\
\text { Bootstrapping over all loci } \\
(1000 \mathrm{BS})\end{array}$}} & 0.773 & 0.707 & 0.754 & 18.2 & $-0.10 \pm 0.016$ & $0.135 \pm 0.015$ & \multicolumn{2}{|c|}{$0.213 \pm 0.012$} \\
\hline & & & & & & & & & \\
\hline & & & & $-0.13--0.07$ & $0.108-0.163$ & \multicolumn{2}{|c|}{$0.019-0.234$} \\
\hline \multicolumn{3}{|l|}{$99 \% \mathrm{CI}$} & & & & $-0.139--0.06$ & $10.099-0.173$ & \multicolumn{2}{|c|}{$0.183-0.239$} \\
\hline
\end{tabular}

LG = Linkage group, $\mathrm{H}_{\mathrm{nb}}$ = unbiased gene diversity, $\mathrm{H}_{\mathrm{o}}=$ observed heterozygosity, PIC = polymorphism information content, $\mathrm{K}=$ total no of alleles, $\mathrm{A}_{\mathrm{r}}=$ Allelic richness, $\mathrm{F}_{\mathrm{is}}=$ inbreeding coefficient of individuals within subpopulations, $\mathrm{F}_{\mathrm{it}}=$ inbreeding coefficient of individuals within total population, $\mathrm{F}_{\mathrm{st}}=$ amount of variation due to differentiation between subpopulations, $\mathrm{CI}=$ Confidence Interval, $\mathrm{NS}=$ not significant at $\mathrm{P}<0.005$. 
Table 4. - Diversity parameters of 11 cacao populations in Nigerian field genebank based on 12 microsatellite markers.

\begin{tabular}{|c|c|c|c|c|c|c|c|c|c|}
\hline & $\mathrm{n}$ & $H_{e}$ & $H_{o}$ & $\mathbf{P}_{(0.95)}$ & $\mathrm{K}$ & A & $\mathrm{A}_{e}$ & $A_{p}$ & $F_{i s}$ \\
\hline $\mathrm{F}_{1}$ Hybrid & 28 & 0.70 & 0.79 & 1.00 & 67 & 7.25 & 4.34 & 0.42 & -0.108 \\
\hline $\mathrm{F}_{2}$ Hybrid & 41 & 0.60 & 0.69 & 1.00 & 47 & 6.08 & 3.27 & 0.17 & -0.138 \\
\hline GB-S & 22 & 0.57 & 0.56 & 1.00 & 46 & 5.75 & 2.70 & 0.25 & 0.050 \\
\hline GB-TRD & 17 & 0.61 & 0.68 & 0.92 & 44 & 5.67 & 3.03 & 0.58 & -0.087 \\
\hline LOCAL & 15 & 0.50 & 0.59 & 1.00 & 36 & 3.92 & 2.18 & 0.17 & -0.145 \\
\hline AMEL & 22 & 0.20 & 0.18 & 0.50 & 20 & 3.25 & 1.34 & 0.17 & 0.142 \\
\hline IMC & 13 & 0.57 & 0.73 & 1.00 & 40 & 4.00 & 2.55 & 0.0 & -0.236 \\
\hline NA & 20 & 0.51 & 0.53 & 0.92 & 40 & 5.08 & 2.52 & 0.0 & -0.001 \\
\hline PA & 17 & 0.50 & 0.51 & 0.92 & 35 & 3.58 & 2.26 & 0.08 & 0.013 \\
\hline SCA & 10 & 0.55 & 0.66 & 1.0 & 50 & 4.17 & 2.46 & 0.75 & -0.152 \\
\hline TRIN & 29 & 0.58 & 0.73 & 1.0 & 33 & 4.67 & 2.47 & 0.25 & -0.230 \\
\hline
\end{tabular}

$\mathrm{n}=$ number of samples, $H_{\mathrm{e}}=$ expected heterozygosity, $H_{0}=$ observed heterozygosity, $\mathrm{P}_{(0.95)}=$ proportion of polymorphic loci when most frequent allele does not exceed $95.0 \%, \mathrm{~K}=$ number of alleles with frequency $>5.0 \%$ in each population, $\mathrm{A}=$ Mean number of alleles per locus, $A_{\mathrm{e}}=$ effective number of alleles, $F_{i s}=$ inbreeding coefficient of individuals within subpopulations obtained from 1000 Bootstrap at probability level at $95 \%$.

\section{Data analysis}

In the first step of analysis, an assignment test based on Bayesian method (Table 1) was carried out to verify genetic identity of accessions in the 11 populations including parental clones representing primary reference populations such as Nanay (NA), Parinari (PA), Scavina (SCA), Trinitario (TRIN), Amelonado (AMEL) and Local Selection (LOCAL) populations. Five Amelonado reference samples (SIAL 20, SIAL 70, SIAL 84, SIC 19 and SIC 23) were included in the assignment test. The assignment probabilities were computed for each individual to determine the degree to which its genome was classified into each cluster. Assignment of individu- als into the a priori primary populations (PA, NA, IMC, SCA, TRINITARIO and LOCAL) was set at not $<90 \%$ probability. Individuals in the a priori grouping that did not meet the criteria were considered as mislabeled and excluded from subsequent analysis. The program GENALEX ver. 6 (PEAKALL and SMOUSE, 2005) was used for the assignment test.

Genetic diversity within and among loci and populations was estimated using the software package GENALEX ver. 6, GENETIX 4.0.2 (BELKHIR, 2001) and FSTAT ver. 2.9.3 (GOUDET, 2001) for the following statistics: allelic frequencies, effective number of alleles $\left(A_{e}\right)$ per locus for each population (the measure of the num-

Table 5. - Analysis of molecular variance (AMOVA) for microsatellite variation in 11 populations of cacao in Nigerian field genebank.

\begin{tabular}{lllllll}
\hline Source & df & SSD & MSD & $\begin{array}{l}\text { Variance } \\
\text { component }\end{array}$ & \% Total & P-value \\
& & & & & & \\
\hline Among pops & 10 & 793.64 & 79.36 & 3.50 & 37.0 & 0.0001 \\
Within pops & 223 & 1345.04 & 6.03 & 6.03 & 63.0 & 0.0001 \\
F 1 Hybrid & 28 & 206.02 & 7.36 & - & - & - \\
F $_{2}$ Hybrid & 41 & 249.43 & 6.08 & - & - & - \\
GB-S & 22 & 155.90 & 7.09 & - & - & - \\
GB-TRD & 17 & 110.17 & 6.48 & - & - & - \\
LOCAL & 15 & 73.95 & 4.93 & - & - & - \\
AMEL & 22 & 60.12 & 2.73 & - & - & - \\
IMC & 13 & 64.76 & 4.98 & - & - & - \\
NA & 20 & 119.85 & 5.99 & - & - & - \\
PA & 17 & 99.46 & 5.85 & - & - & \\
SCA & 10 & 52.30 & 5.23 & - & - & \\
TRINITARIO & 29 & 153.09 & 5.28 & - & - & - \\
Total & 234 & 2138.69 & 9.14 & - & - & - \\
& & & & & & - \\
\hline
\end{tabular}

PhiPT $=0.367 ; \mathrm{N} 0=20.94$ obtained from 9999 pairwise poplation permutations 

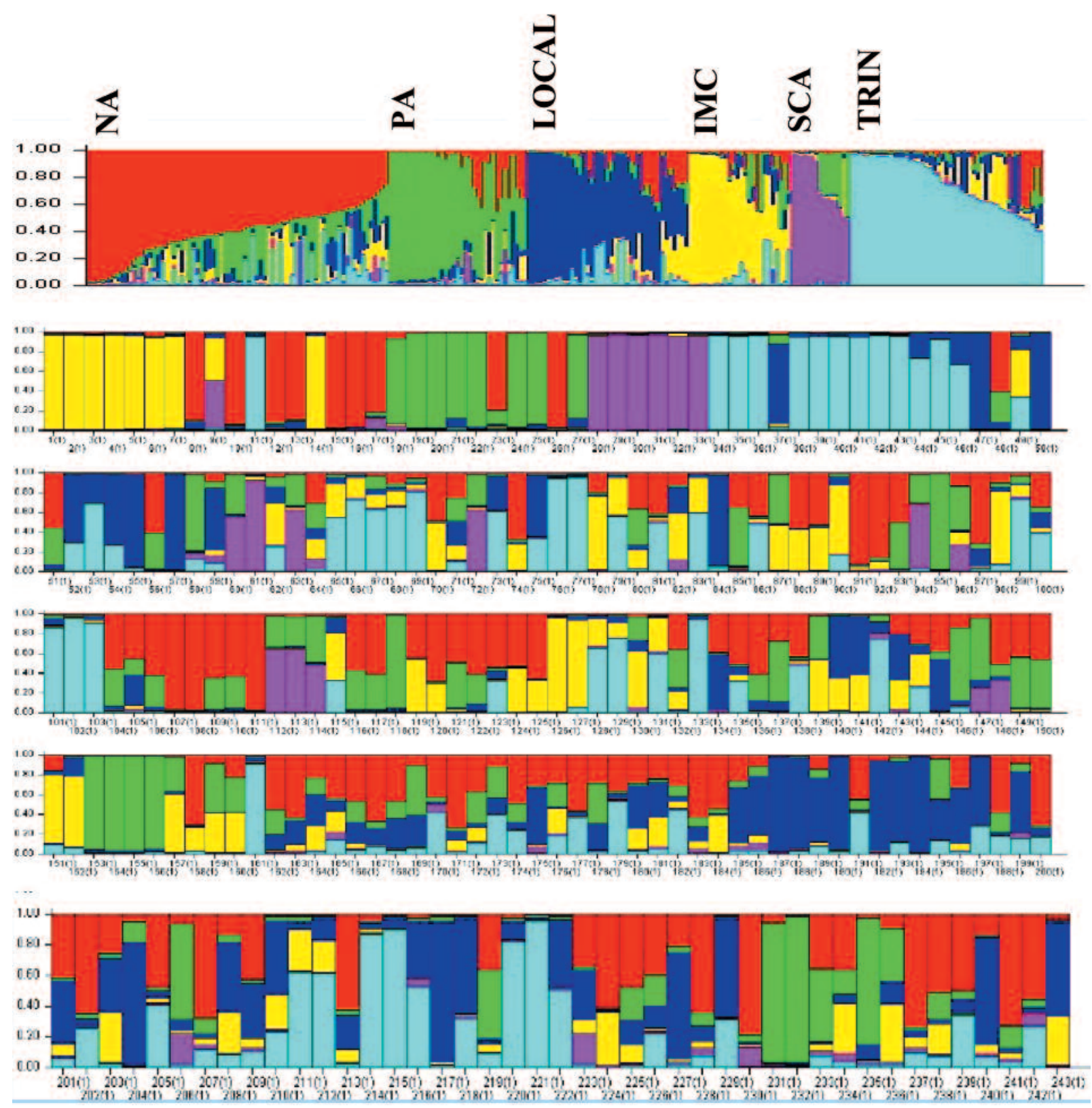

Figure 1. - Optimum alignment generated with CLUMPP (JAKOBSSON and ROSENBERG, 2007) from analysis of 243 accessions set at with $\mathrm{k}=6$ at 200,000 iterations after a burn-in period of 100,000 using STRUCTURE (PRITCHARD et al., 2000). Label 1-7 = IMC, 8-17 = NA, 18-27 = PA, 28-33 = SCA, 34-43 = TRIN, 44-57 = LOCAL, 58-161 = F Hybrid, 162-181 = $\mathrm{F}_{2}$ Hybrid, 182-229 = GB-S, 230-243 = GB-TRDI. NA = Nanay, PA = Parinari, LOCAL = Local Selections, SCA = Scavina, IMC = Iquitos Mixed Calabacillo, and, TRIN = Trinitario.

ber of alleles per locus independent of sample size), expected $\left(H_{e}\right)$ and observed heterozygosity $\left(H_{o}\right)$ (NEI, 1978). Standard errors for the above parameters and confidence intervals at $95 \%$ and $99 \%$ levels were estimated over all loci by bootstrapping (1000 bootstraps) and jackknifing (QUENOILLE, 1956; EFRON, 1982) using 1000 replications. Genetic differentiation for polymorphism between pairs of populations was analyzed by Fstatistics estimator, $F_{s t}(\theta)$ (WRIGHT, 1965), as described by WEIR and COCKERHAM (1984) based on 1000 permutations. $F_{s t}(\theta)$ values were then subjected to standard Bonferroni corrections (HoLM, 1979; RICE, 1989) to guide against type I error. Exact test of deviation of fixation indices for each locus from Hardy-Weinberg equilibrium was done with TFPGA (MiLLER, 1997) software. For each SSR marker, the polymorphism information content (PIC) value was calculated according to PowELL et al. (1996) using the computer program CERVUS (MARSHALL, 1998). Genetic distance between pairs of population was estimated based on unbiased minimum genetic distance $\left(\mathrm{D}_{j}\right)$ according to NEI (1978) and clustered based on UPGMA using TFPGA (MILLER, 1997).

Genetic structure in the genebank was determined by a hierarchical analysis of molecular variance (AMOVA, EXCOFFIER et al., 1992), implemented in GENALEX ver.6. The total molecular variance was partitioned as among population and individuals within population. The significance of $\Phi$ statistics was tested by permuta- 
tion with 1,000 randomizations for probability of nondifferentiation.

Population structure inference and ancestry of 243 samples were assessed with a Bayesian model-based clustering method, implemented in STRUCTURE (PRITCHARD et al., 2000). Based on the known number of parental groups, the $k$ value was set from 5 to 7 and the analysis was carried out in 200,000 iterations after a burn-in period of 100,000 . Twenty independent runs were assessed for each $k$ value. Results of the five iterations with highest score in each replicated run were combined using CLUMPP to generate the optimum alignment (JAKOBSSON and RosenBERG, 2007). Pair-wise genetic distances among individuals were computed in GENETIX 4.0.2 (BELKHIR, 2001) and presented on a three-dimensional scale plot using factorial analysis of correspondences (FAC) implemented in the same program.

\section{Results}

\section{Assignment test and identification of mislabeling}

With the prior classification of the genebank accessions into 11 population groups, the assignment test
(Table 1) showed an error rate between $0.0 \%$ (IMC, SCA, AMEL) and 20\% (NA, PA) in the parental accessions but higher error rate between $5.0 \%$ ( $\mathrm{F}_{2}$ Hybrid) and $73.1 \%\left(\mathrm{~F}_{1}\right.$ hybrid) in the rest populations. For instance, in the NA population, two accessions, NA 48 and Ghn-NA31 were detected as off-types belonging to Trinitario and IMC populations, respectively. Accessions labeled PA 35 and PA7 in the field genebank were also detected as off-types. An accession labeled Nig-ICS1 in the Trinitario population was assigned to the Local Selection group. In spite of this high error rate in the a priori classification, the assignment test was able to correctly assign $93.6 \%$ of individuals in their appropriate population groups. Sixteen incorrectly assigned and mislabeled individuals were excluded from subsequent analysis.

The assignment test also gave a clear differentiation among accessions in the Local Selections group (Table 2) originally classified based on pod colour as 'local Amelonado' (green pods) or 'local Trinitario' (red pods). Accessions C17, C21, C26 and N38 were classified as truly Amelonado sharing profiles with the reference SIC and SIAL Amelonado reference samples. Clone C14 was classified into Trintario group, sharing profiles with

Table 6. - Pairwise estimate of $F_{s t}(\theta)$ for differentiation between pairs of populations over 12 microsatellite loci in Nigeria's Theobroma cacao genebank collection.

\begin{tabular}{|c|c|c|c|c|c|c|c|c|c|c|}
\hline & $\begin{array}{l}\mathrm{F}_{2} \\
\mathrm{Hyb}\end{array}$ & GB-S & $\begin{array}{l}\text { GB- } \\
\text { TRD }\end{array}$ & LOCAL & AMEL & IMC & NA & PA & SCA & TRIN \\
\hline$F_{1}$ Hybrid & 0.072 & 0.085 & 0.048 & 0.165 & 0.322 & 0.115 & 0.111 & 0.110 & 0.197 & 0.183 \\
\hline $\mathrm{F}_{2}$ Hybrid & & 0.059 & 0.037 & 0.129 & 0.257 & 0.216 & 0.091 & 0.161 & 0.285 & 0.191 \\
\hline GB-S & & & 0.121 & 0.074 & 0.166 & 0.221 & 0.204 & 0.189 & 0.288 & 0.156 \\
\hline GB-TRD & & & & 0.199 & 0.391 & 0.200 & 0.086 & 0.124 & 0.262 & 0.232 \\
\hline LOCAL & & & & & 0.116 & 0.282 & 0.307 & 0.246 & 0.355 & 0.120 \\
\hline AMEL & & & & & & 0.502 & 0.491 & 0.403 & 0.565 & 0.339 \\
\hline IMC & & & & & & & 0.218 & 0.322 & 0.302 & 0.304 \\
\hline NA & & & & & & & & 0.295 & 0.325 & 0.328 \\
\hline PA & & & & & & & & & 0.369 & 0.281 \\
\hline SCA & & & & & & & & & & 0.338 \\
\hline
\end{tabular}

Values $(\mathrm{p}<0.0001)$ obtained from 10,000 permutations.

Table 7. - Estimate of NeI's (1978) unbiased minimum distance between primary cacao populations and groups in Nigeria's germplasm collection. LOCAL $=$ Local selections, TRIN = Trinitario, $\mathrm{IMC}=$ Iquitos Mixed Calabacillo, NA = Nanay, $\mathrm{PA}=$ Parinari, $\mathrm{SCA}=$ Scavina, $\mathrm{GB}=$ Genebank, $\mathrm{TRD}=$ Trinidad Introduction .

\begin{tabular}{|c|c|c|c|c|c|c|c|}
\hline & \multicolumn{7}{|c|}{ Nei's minimum distance } \\
\hline & LOCAL & AMEL & IMC & NA & PA & SCA & TRIN \\
\hline $\mathrm{F}_{1}$ Hybrid & 0.127 & 0.23 & 0.086 & 0.079 & 0.079 & 0.165 & 0.144 \\
\hline $\mathrm{F}_{2}$ Hybrid & 0.085 & 0.159 & 0.163 & 0.057 & 0.110 & 0.235 & 0.139 \\
\hline GB-S & 0.045 & 0.079 & 0.166 & 0.144 & 0.130 & 0.236 & 0.108 \\
\hline GB-TRD & 0.139 & 0.239 & 0.149 & 0.053 & 0.079 & 0.213 & 0.180 \\
\hline Local & - & 0.041 & 0.212 & 0.230 & 0.166 & 0.293 & 0.074 \\
\hline
\end{tabular}




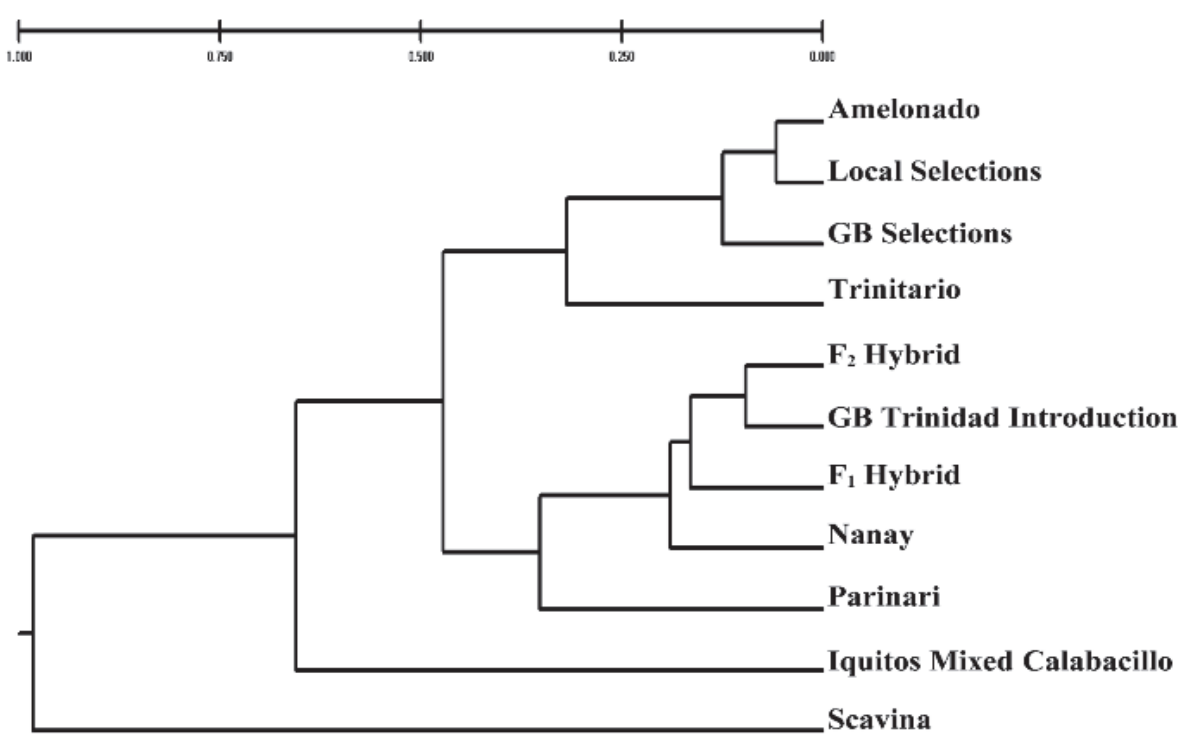

Figure 2. - Dendrogram of 11 cacao populations (including 234 accessions) in Nigerian cacao field genebank collection.

Trinidad's ICS reference clones. However, clones C13, C16, C23, C24 and C25, originally classified as 'Local Trinitario', were found to share alleles with local Amelonado. On the other hand, Clones C19, C22 and C27 were assigned as Upper Amazon's NA x PA hybrids and C20 as IMC x Trinitario hybrid from the Bayesian clustering implemented in STRUCTURE program (Table 2).

\section{Genetic diversity assessment}

A total of 218 alleles were obtained from the 234 accessions using 12 microsatellite loci (Table 3). The mean number of alleles per SSR locus (18.2) ranged from 14 for $m T c C I R 17$ to 24 for $m T c C I R 18$. However, the mean expected heterozygosity ranged from 0.512 for $m T c C I R 24$ to 0.903 for $m$ TcCIR3. The mean polymorphism information content $(P I C)$ of the markers was 0.754 and ranged from 0.497 for $m$ TcCIR24 to 0.892 for $m T c C I R 3$. Fixation index $\left(F_{i s}\right)$ indicated excess of heterozyzotes for all 12 loci, eight of which showed significant deviation from Hardy-Weinberg equilibrium (Table 4). However, the average fixation index indicated a general deficit of heterozygotes among sub-populations $\left(F_{s t}=0.213\right)$ and total population $\left(F_{i t}=0.135\right)$.

The mean number of alleles per locus for all 11 populations ranged from 3.25 for Amelonado population to 7.25 for $\mathrm{F}_{1}$ Hybrid population (Table 4). The effective number of alleles per locus also ranged from 1.34 in Amelonado population to 4.34 in the $\mathrm{F}_{1}$ Hybrid population. However, the number of private alleles was highest in the Scavina population (0.75), while the IMC and NA population had none. The mean gene diversity $\left(H_{e}\right)$ ranged from 0.20 for the Amelonado to 0.70 for $\mathrm{F}_{1}$ Hybrid population. The pattern of observed heterozygosity $\left(H_{o}\right)$ was not different from the expected $\left(H_{e}\right)$ but generally lower than the expected heterozygosity, except for Amelonado and Genebank Selection populations (Table 4). The number of alleles present was highest in the $\mathrm{F}_{1}$ hybrid' population $(\mathrm{k}=67)$ and followed by Scavina $(\mathrm{k}=50)$. It was lowest in Amelonado $(\mathrm{k}=20)$ and followed by Trinitario $(\mathrm{k}=33)$. The Fixation index $\left(F_{i s}\right)$ was positive and indicated deficiency of heterozygotes in the Amelonado (0.142), Genebank Selection (0.050) and PA (0.013) populations (Table 4). On the other hand, it was negative for the rest populations such as IMC (-0.236), Trinitario $(-0.230)$ and Local Selection $(-0.145)$. This indicated that there was a significant excess of heterozygotes in these populations.

\section{Population structure and genetic relationships}

AMOVA showed that majority of the molecular variance $(63.0 \%)$ was contributed by the within-population variance (Table 5). The among-population variance accounted for $37.0 \%$ of total variance. The population structure inference and ancestry assessed with a Bayesian model clustering method (Figure 1), based on known parental groups implemented in STRUCTURE (PRITCHARD et al., 2000) distinctly separated the IMC, NA, PA, SCA, Trinitario and Local Selection populations. However, the ancestry inference of accessions in the rest genebank populations indicated that they were mainly hybrids. Mislabeled and wrongly classified accessions were also identified.

Genetic differentiation between pairs of population (Table 6) estimated with $F_{s t}$ (theta) showed that the $\mathrm{F}_{1}$ Hybrid population showed less differentiation from $\mathrm{F}_{2}$ Hybrid, Genebank Trinidad Introduction and Genebank Selection than the other populations. Local and Genebank Selection also showed much less differentiation than others. The Nanay population showed the least differentiation from $\mathrm{F}_{2}$ Hybrid and Genebank Trinidad Introduction than the other populations. The estimated unbiased minimum distance between pair of populations (Table 7) showed that $\mathrm{F}_{1}$ Hybrid population had greater relationship with the PA, NA and IMC populations, while $\mathrm{F}_{2}$ hybrid population was more related to NA and Local Selection populations. The NA and PA parental populations were more related to the Genebank Trinidad Introduction, while Local Selection and Amelonado populations were more related to the Genebank Selection population than others. The Local 


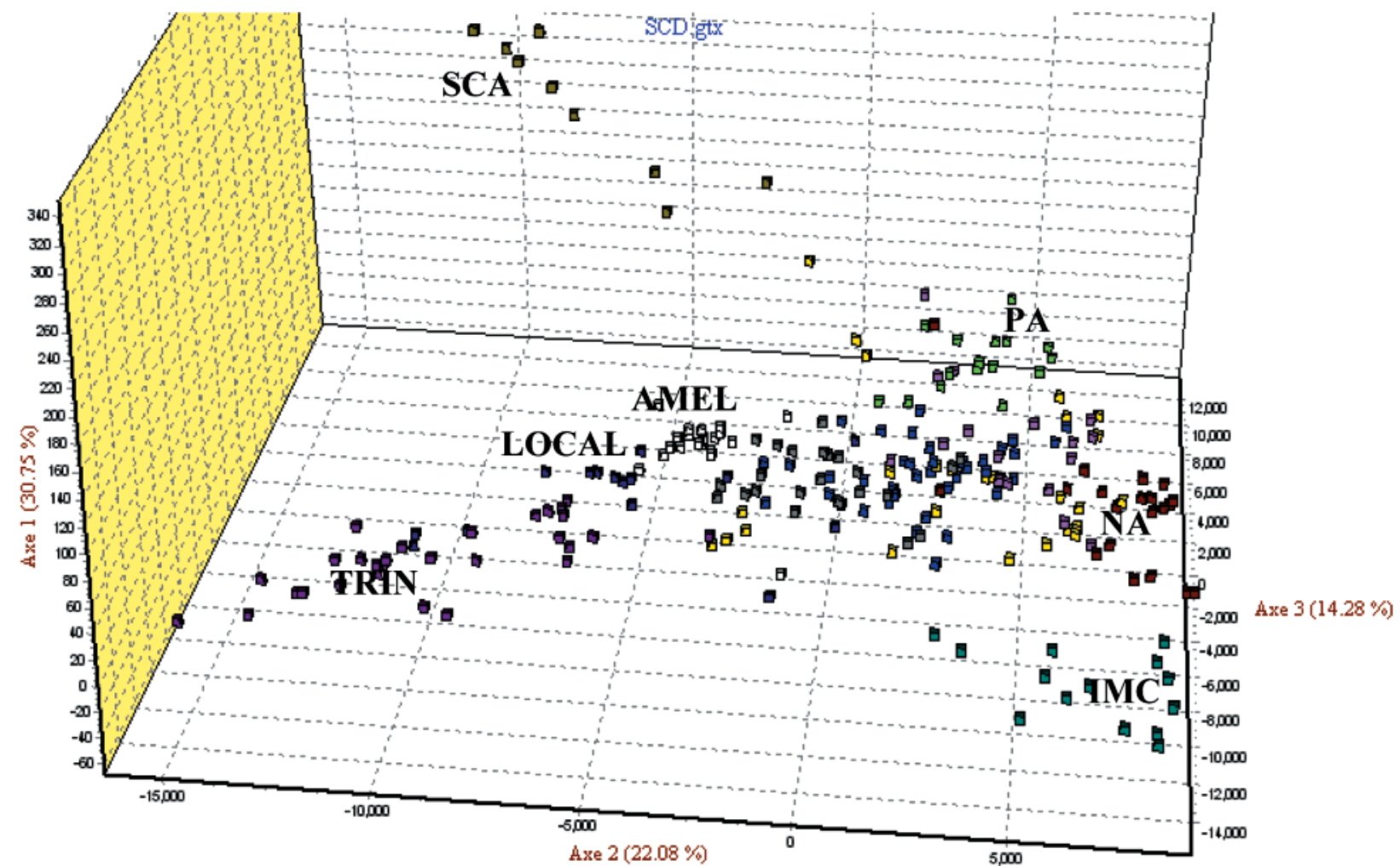

Figure 3. - Factorial analysis of correspondence (FAC) accounting for $67.1 \%$ of total variation showing relationships among accessions in the 11 population groups of cacao in the Nigerian field genebank collections. Legends are $=\mathrm{F}_{1}$ hybrid, $\mathbf{=}=\mathrm{F}_{2}$ hybrids, $\mathbf{\square}=$ Genebank selections, and $\mathbf{\square}=1967$ Genebank Trinidad Introduction. Other populations, Trinitario (TRIN), Scavina (SCA), Parinari (PA), Nanay (NA), Amelonado (AMEL), Local Selection (LOCAL) and Iquitos Mixed Calabacillo (IMC) are shown on the graph.

Selection population was most related to the Amelonado and Trintario populations.

The genetic relationship among the 11 populations is illustrated by the dendrogram in Figure 2 . The 11 populations were divided into two main subsets. The first subset consisted of the Local Selection, Genebank Selection, Amelonado and Trinitario populations. Amelonado and Trinitario populations appeared to have provided parentage to accessions of the Local and Genebank Selection population groups in this subset. The second subset consisted of $\mathrm{F}_{1}$ Hybrid, $\mathrm{F}_{2}$ Hybrid, Genebank Trinidad Introduction, which appeared to have drawn parentage largely from the Nanay and Parinari populations. The Scavina and IMC populations appeared distantly related to the two main subsets. Factorial analysis of correspondence (Figure 3) accounting for $67.1 \%$ of total variance illustrates the relationships among field genebank accessions in the various population groups. It showed that accessions in the field genebank were more closely related to Nanay, Parinari, and Local Selections than to the Trinitario, Scavina and IMC populations which were clearly separated.

\section{Discussion}

The knowledge of the nature and amount of genetic diversity present in a germplasm collection is a major pre-requisite for exploitation of useful diversity in development of improved cultivars in breeding programs. The development of cacao microsatellite markers (LANAUD et al., 1999; PUGH et al., 2004), and the optimization of fingerprinting procedures (ZHANG et al., 2006a; CRYER et al., 2006) have opened new opportunities to use microsatellite markers to both fingerprint and determine genetic diversity of germplasm collections. Until this study, there was no information available on the genetic structure of cacao genetic resources in Nigeria that has been used in more than seven decades of formal selection and breeding programme.

\section{Verification of genetic identity and identification of mislabeled accessions}

Although mislabeling and misidentification has been known in cacao collections, it was only recently that these have been estimated with the use of molecular markers (MOTILAL and BUTLER, 2003; BOCCARA and ZHANG, 2006; ZHANG et al., 2008). The assignment test determines the population of origin of a single individual through Bayesian method (PRITCHARD et al., 2000). This method needs only relatively small number of loci to detect a very strong signal of population structure and assign individuals appropriately. This has been used successfully to determine the structure of the cacao primary genepool (MOTAMAYOR et al., 2008), 'Refractarios' (ZHANG et al., 2008). Until this study, there has been no such information on cacao germplasm collections maintained in Nigeria.

In this study, we found that a number of accessions that were wrongly identified. For instance, accessions labeled Ghn-NA31, PA 35 and PA7 was found to be off- 
types. The genetic structure of the Local Selection population, originally classified based on pod colour as 'local Amelonado' (green pods) or 'local Trinitario' (red pods) was also elucidated with the assignment test used in this study. Accessions C17, C21, C26 and N38 were classified as truly Amelonado sharing profiles with SIC and SIAL Amelonado reference samples, while C14 was classified as Trintario, sharing profiles with Trinidad's ICS Trinitario reference clones. However, clones C13, C16, C23, C24 and C25 which were also originally referred to as Local Trinitario were found having Amelonado ancestry, indicating the hybrid nature of these clones. These clones could therefore be classified as 'Trintario-Amelonado' hybrids, and, distinguished from C14 with same SSR profiles as Trinitario ICS clones. A more surprising finding was the ancestry of clones C19, C22 and C27 that were assigned as Upper Amazon's NA x PA hybrids and C20 as IMC x Trinitario hybrid. These clones were originally believed to be Local Amelonado or Local Trinitario. This provides a very important clue to a limitation in past breeding programmes where these wrongly identified materials had been used in variety development. ROB LOCKWOOD (personal communication) had observed that the tree morphology and growth pattern of C19, C22 and C27, was atypical of local Amelonado, and had cast some doubt on their identity as Amelonado. However, till this study, there had been no scientific proof to support this observation. This finding that these local clones shared allelic profiles with Upper Amazon's Nanay, Parinari and Iquitos Mixed Calabacillo primary populations, therefore, indicated that cultivation of cacao having some Upper Amazon genetic background by local farmers in West Africa, especially Ghana and Nigeria predated the Posnette's 1944 Introduction, widely believed to be the first source of materials from the Upper Amazon population in West Africa. It also showed that apart from the Bahian 'Comum' Amelonado cocoa and red-podded Trinitario cocoa that were regarded as the base population in farmers' fields, some materials of Upper Amazon population had also reached farmers' plots before the inception of organized breeding programme in the early 1930 s by the colonial administration in Nigeria. BARTLEY (2005) mentioned that although there had not been records of the original plantings, some varieties from Ecuador, Trinidad and Venezuela were introduced into Sao Tome around 1880, besides earlier introduction of Amelonado from Bahia in 1822. Seeds from these introduced materials were distributed to several farms during a period of active cultivation expansion. We can therefore suggest that some materials of Upper Amazon Forastero origin were among earlier materials introduced from Fernando Po into the West African mainland. These non-Amelonado materials could also have been introduced into the country through undocumented means or from other sources as the Kew Botanical Gardens by the colonial administration.

Since the structure analysis showed that a large percentage of the accessions were hybrids, it would be necessary to determine the ancestry of these accessions in order to facilitate their effective utilization in breeding program. The correctly verified accessions will also be useful as reference materials in the collection while mis- labeled ones are removed from the genebank. This study provides a basis for the rationalization of the Nigerian field genebank collection of cacao in view of the cost and mislabeling problems involved in maintaining living tree collections.

\section{Population structure and genetic variation}

In this study, a total of 218 alleles were revealed from 12 microsatellite markers used to determine the genetic diversity in 11 populations consisting of 234 clones and accessions sampled from the germplasm repository of the Cocoa Research Institute of Nigeria. High levels of polymorphism were observed in the loci used with the number of alleles generally higher than reported by LANAUD et al., 1999 (Table 2). While equal number of alleles as observed by LANAUD et al. (1999) for $m T c C I R 6$, $m T c C I R 18$ and $m$ TcCIR25 were obtained in the samples studied, certain markers exhibited an up to three-fold increase in numbers of alleles. For instance, 23 alleles per locus were obtained for mTcCIR3 against 6 alleles per locus reported by LANAUD et al. (1999). The higher number of alleles obtained in this study could be explained by the higher number of samples, different genotypes and use of capillary electrophoresis (CE) system which allowed the detection of more alleles as could not be done with gel-based staining system, as was also observed by SERENO et al. (2006). Capillary electrophoresis is a high throughput system that allowed detection of a single base pair difference and is highly reproducible between laboratories (ZHANG et al., 2006a; CRYER et al., 2006).

Although gene diversity was low for the Amelonado population, it was generally high in the other field genebank collections ranging from 0.500 in the Local Selection to 0.70 in the $F_{1}$ Hybrid population. The $F_{1}$ hybrid population introduced into West Africa from Trinidad in 1944 (PosNETTE and TODD, 1951) presents a unique genetic makeup. The high genetic diversity $\left(H_{n b}=0.70\right)$ indicated high amount of genetic diversity in this population and the highest number of alleles per locus (7.25). This is an important source of genetic diversity that could be exploited to deal with production problems such as resistance to Phytophthora pod rot and drought. This wide genetic background which cuts across major primary populations could have been responsible for the large amount of gene diversity observed in this population. Although largely of Upper Amazon origin, a good proportion of the $F_{1}$ hybrid population which constituted the T-Clones used in the West African cocoa breeding programmes were of Trinitario and Criollo origin. Out of 59 hybrid crosses of the first batch of this population where only the mother tree is known, 27 are of Criollo and Trinitario origin, 15 of Upper Amazon, and eight were obtained from Ecuador. In the second batch of bi-parental crosses of known parents, 16 were of full sib Upper Amazon origin; five of Upper Amazon x Criollo or Trinitario, and eight of Trinitario or non-Upper Amazon origin. This wide genetic background could have been responsible for the large amount of gene diversity observed in this population and the large number of rare and distinct alleles not present in their Upper Amazon Forastero or Trinitario parents. This could be explained by a large proportion of 
this population that was obtained from open pollinated mother trees (T1-T59) (ToxopeUs, 1964). It would be important to further study this unique population not present anywhere else in the world for any unique attributes these clones might possess. SERENO et al. (2006) also stressed the importance of germplasm collections when they found several distinct alleles in $\mathrm{CAB}$ (Cacao Amazon Brazil) accessions collected from Lower Amazon region such as Alenquer, Para State in Brazil (BARTLEY, 2005).

Examination of the fixation index showed a significant deficiency of heterozygotes in Amelonado population which is consistent with reports by other workers (Motamayor et al., 2008; SERENo et al., 2006). The inbreeding coefficient $\left(F_{i s}\right)$ is one of the most important parameters used to describe the mating systems in flowering plants and inference is drawn from the distribution of allelic variation into genotypes and by comparison of observed genotypic proportions with those expected at Hardy-Weinberg equilibrium (HAYATI et al., 2004; OHTSUKA et al., 2005). Iquitos Mixed Calabacillo, Scavina, $\mathrm{F}_{1}$ Hybrid, $\mathrm{F}_{2}$ Hybrid, Genebank Trinidad Introduction and Local Selection populations exhibited significant excess of heterozygotes. This indicated an outcrossing mating system and preponderance of self-incompatibility in these populations. On the other hand, Parinari, Genebank Selection and Amelonado populations showed deficit of heterozygotes. This suggests a tolerance to inbreeding in these populations. Studies have shown that degree of selfing varies often within a genus or within a species (SWEIGART et al., 1999; OHTSUKA et al., 2005). This implies a need to study the compatibility status of the genebank entries in order to determine the self-compatibility status, or otherwise, of the accessions to facilitate their effective utilization in breeding program.

Estimate of pair wise genetic differentiation among the populations indicated that significant differentiation occur between the pairs of population. However, it appeared that $\mathrm{F}_{2}$ hybrid population and Genebank Trinidad introduction are less differentiated as the case with the Local Selection and Genebank Selections' populations. The latter situation could have been due to the use of clones in the Local Selections group in the development of population in the Genebank Selections population, such as the WACRI Series II variety which was a cross between Local Selections and some $\mathrm{F}_{1}$ hybrid clones (ATANDA, 1975). The genetic differentiation of the Genebank Selections population from the $\mathrm{F}_{1}$ hybrid, $\mathrm{F}_{2}$ Hybrid and Upper Amazon populations indicated that only a small proportion of the genetic diversity in these groups have been utilized in variety development in more than four decades of cocoa breeding research at the Cocoa Research institute of Nigeria.

In an attempt to determine the level of utilization of the genetic diversity present in the genebank and populations that have had influence on varieties developed and distributed to farmers, results obtained showed clearly that the Upper Amazons Nanay, Parinari and Iquitos Mixed Calabacillo are the main ancestral progenitors of $\mathrm{F}_{1}$ Hybrid population. However, the Nanay population contributed largely to the $\mathrm{F}_{2}$ Hybrid popula- tion. The Genebank Selections derived mainly from Local and Amelonado. The Local Selection population derived mainly from the Amelonado and Trinitario population. The cluster diagram also showed that Upper Amazons Scavina, Iquitos Mixed Calabacillo and Trinitario populations are yet to be significantly exploited in variety development efforts. Moreover, the higher proportion of private alleles in Scavina, Genebank Trinidad Introduction and $\mathrm{F}_{1}$ Hybrid populations showed that they are yet to be fully exploited for variety development. Important alleles locked up in these populations may be useful to address key production constraints. For instance, useful resistance to Phytophthora pod rot and witches broom associated with the Scavina population and the large bean size of Iquitos Mixed Calabacillo population may have been little utilized in the breeding program. In this study, we showed that only a small proportion of genetic diversity available in the Nigerian germplasm collection has been utilized for the development of improved varieties distributed to farmers. Most of clones that have been used in cacao breeding at CRIN have originated mainly from the Parinari and Nanay populations and the bulk of the 1967 Trinidad Introduction materials used were mainly intra-Nanay and intraParinari crosses (ATANDA, 1975; OJO et al., 1991). This study revealed the need for guided exploitation of useful diversity in Scavina and Iquitos Mixed Calabacillo populations for development of cultivars to address production problems such as Phytophthora pod rot, swollen shoot virus disease and bean quality in future breeding program.

\section{Acknowledgement}

This study was part of the first author's Ph.D research and financially supported by UNITED STATES DEPARTMENT OF AGRICULTURE (USDA), MARS INCORPORATED AND United States Agency for International Development (USAID) through the Norman Borlaug LEAP (LEADERShIP Enhancement IN AGRICUltural Program) Fellowship Award to the first author. The field and laboratory support of MESSRS. RAJI LO, EFUNLA MS (CRIN), SUNDAY TAIWO (IITA), WILbER QUinternella, NANNETTE LANGevin AND CECILE Olano (USDA-ARS SHRS Miami) are highly appreciated. The authors are also grateful to Dr. DAPENG ZHANG (USDA-ARS BELTSVILle) for STRUCTURE analysis of the data. The useful suggestions of the two anonymous referees are gratefully acknowledged.

\section{References}

AIKPOKPODION, P. O. (2007): Genetic diversity in Nigerian cacao, Theobroma cacao L. collections as revealed by phenotypic and simple sequence repeats marker. $\mathrm{PhD}$ Thesis submitted to the University of Ibadan, Nigeria. $147 \mathrm{pp}$.

AikPokPodion, P. O., J. C. Motamayor, V. O. Adetimirin, Y. Adu-Ampomah, I. Ingelbrecht, A. B. Eskes, R. J. SCHNEll and M. Kolesnikova-Allen (2009): Genetic diversity assessment of sub-samples of cacao, Theobroma cacao L. collections in West Africa using simple sequence repeats marker. Tree Genetics \& Genomes 5: 699-711. 
Alverson, W. S., B. A. Whitlock, R. Nyfeller, C. Bayer and D. A. BAUM (1999): Phylogeny of the core Malvales: Evidence from $n d h F$ sequence data. American Journal of Botany 86: 1474-1486.

AtANDA, O. A. (1975): Assessment of WACRI Series I and II varieties of cocoa in Nigeria. 2. Pod value, butter fat content and flavour assessment. Ghana Journal of Agricultural Science 8: 3-10.

BARTLEY, B. G. D. (2005): The genetic diversity of cacao and its utilization CABI Publishing, United Kingdom $341 \mathrm{pp}$.

BelkhiR, K., P. Borsa, L. ChiKhi, N. Raufaste and F. BonHOMME (2001): GENETIX 4.02, logiciel sous Windows TM pour la génétique des populations, Laboratoire Génome, Populations, Interactions: CNRS UMR. 5,000, Université de Montpellier II, Montpellier, France

Bhattacharjee, R., M. Kolsnikova-Allen, P. O. AikpoKPODION, S. TAIWO and I. INGELBRECHT (2004): An improved semi-automated rapid method of extracting genomic DNA for molecular marker analysis in cocoa, Theobroma cacao L. Plant Molecular Biology Reporter 22: $435 \mathrm{a}-435 \mathrm{~h}$.

BoccARA, M. and D. ZHANG (2006): Progress in resolving identity issues among the Parinari accessions held in Trinidad: the contribution of the collaborative USDA/CRU project. In: Proceedings of the CRU annual report 2005, Cacao Research Unit, The University of the West Indies, St. Augustine, Trinidad and Tobago.

Cheesman, E. E. (1944): Notes on nomenclature, classification and possible relationships of cacao populations. Tropical Agriculture 21: 144-159.

CuATrecasas, J. (1964): Cacao and its allies: A taxonomic revision of the genus Theobroma. Contributions to the U.S. Natural Herbarium 35(6): 379-614.

Cryer, N. C., M. G. E. Fenn, C. J. Turnbull and M. J. WILKInson (2006): Allelic Size Standards and Reference Genotypes to Unify International Cocoa (Theobroma cacao L.) Microsatellite Data. Genetic Resources and Crop Evolution 53: 1643-1652.

EFron, B. (1982): The jackknife, the bootstrap and other resampling plans. NSF-CBMS Regional Conference Series in Applied Mathematics, Monograph 38. Society for Industrial and Applied Mathematics (SIAM), Philadelphia, Pennsylvania.

Excoffier, L., P. E. Smouse and J. M. Quattro (1992): Analysis of molecular variance inferred from metric distances among DNA haplotypes: application to human mitochondrial DNA restriction data. Genetics 131: 479-491.

GoUDET, J. (2001): FSTAT, a program to estimate and test gene diversities and fixation indices (version 2.9.3). Updated from Goudet (1995) Available from http://www.unilch/izea/softwares/fstat.html.

Guiltinan, M. J. (2007): Cacao. Biotechnology in Agriculture and Forestry, Vol. 60. In: Transgenic Crops V (ed. PuA, E. C., DAvey, M. R.). Springer-Verlag Berlin Heidelberg

HAYATI, A., R. WiCKNESWARI, I. MAIZURA and N. RAJANAIDU (2004): Genetic diversity in oil palm (Elaeis guineensis Jacq.) germplasm collections from Africa: implications for improvement and conservation of genetic resources. Theoretical and Applied Genetics 108: 1274-1284.

Holm, S. (1979): A simple sequentially rejective multiple test procedure. Scand J. Stat 6: 65-70.

ICCO: INTERNATIONAL COCOA ORGANIZATION (2008): Quarterly Bulletin Cocoa Statistics. Vol. XXXIV. 2007/2008.
JACoBs, V. J., O. A. AtANDA and L. K. OpeKe (1971): Cacao breeding in Nigeria. In: CRIN Commemorative Publication - Progress in Tree Crops Research in Nigeria pp. 9-12.

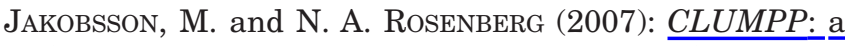
cluster matching and permutation program for dealing with label switching and multimodality in analysis of population structure, Bioinformatics 23: $1801-1806$.

Johnson, E. S., F. L. Bekele, S. J. Brown, Q. Songe, D. Zhang, L. Meinhardt and R. J. Schnell (2009): Population structure and genetic diversity of the Trinitario cacao (Theobroma cacao L.) from Trinidad and Tobago. Crop Sci 49: 564-572.

Lanaud, C., A. M. Risterucci, I. Pieretti, M. Falque, A. Bouet and P. J. L. LAGODA (1999): Isolation and characterization of microsatellites in Theobroma cacao L. Molecular Ecology 8: 2141-2143.

Lockwood, G. and M. M. O. Gyamfi (1979): The CRIG cocoa germplasm collection with notes on codes used in the breeding programme at Tafo and elsewhere. Cocoa Research Institute, Ghana Technical Bulletin No. 10 Tafo.

Marshall, T. (1998): CERVUS v.2.0. University of Edinburgh 1998-2001.

Miller, M. P. (1997): Tools for Population Genetics analysis (TFPGA) version 1.3: a window program for the analysis of allozyme and molecular population genetic data ${ }^{\odot}$. Flagstaff Northern Arizona University, Flagstaff, AZ.

Motamayor, J.-C., A. M. Risterucci, P. A. Lopez, C. F. Ortiz, A. Moreno and C. LAnaud (2002): Cacao domestication I: the origin of the cacao cultivated by the Mayas. Heredity 89: 380-386.

Motamayor, J.-C., A. M. Risterucci, M. Heath and C. LANAUD (2003): Cacao domestication II: progenitor germplasm of the Trinitario cacao cultivar. Heredity 91: 322-330.

Motamayor, J.-C., P. Lachenaud, J. Wallace, G. Loor, D. N. KuHN, J. S. BRown and R. J. SchNeLl II. (2008): Geographic and genetic population differentiation of the Amazonian chocolate tree. PLoS One 3: e3311. doi:10.1007/s12042-008-9011-4

Motilal, L. and D. Butler (2003): Verification of identities in global cacao germplasm collections. Genet Resour Crop Evol 50: 799-807.

Motilal, L., D. Zhang, P. Umaharan, S. Mischke, V. Mooleedhar and L. Meinhardt (2009): The relic Criollo cacao in Belize - genetic diversity and relationship with Trinitario and other cacao clones held in the International Cocoa Genebank, Trinidad Plant Genetic Resources.

NEI, M. (1978): Estimation of average heterozygosity and genetic distance from a small number of individuals. Genetics 89: 583-590.

OHTSUKA, A., M. WATANABE and T. YAHARA (2005): Inbreeding coefficients in six species of Ainsliaea and two species of Pertya (Asteraceae). Plant Syst. Evol. 251: $143-151$.

OJo, A. A., J. O. SANwo and E. B. EsAn (1991): Early results of evaluation of Nanay and Parinari Theobroma cacao double cross progenies in Nigeria. Field Crops Research 27: 257-266.

Olatoye, S. T. and E. B. EsAn (1992): Recent innovation in cacao genetic resources conservation in Nigeria. In: Proceedings of the International Workshop on Conservation, Characterization and Utilization of Cacao Genetic Resources in the $21^{\text {st }}$ Century. Cocoa Research Unit, Port of Spain, Trinidad 13-17 September, 1992 pp. 281-291. 
Peakall, R. and P. E. Smouse (2006): Genalex 6: genetic analysis in Excel. Population genetic software for teaching and research. Mol. Ecol. Notes 6: 288-295.

Posnette, A. F. and J. M. A. TodD (1951): Virus diseases of cacao in West Africa. VIII. The search for virus resistant cacao. Annals of Applied Biology 38: 785-800.

Powell, W., M. Morgante, C. Andre, M. Hanatey, J. Vogel, S. TingeY and A. RAFALSKI (1996): The comparison of RFLP, RAPD, AFLP and SSR (microsatellite) markers for germplasm analysis. Molecular Breeding 2: 225-238.

Pritchard, J. K., M. Stephens and P. Donnelly (2000): Inference of population structure from multilocus genotype data. Genetics 155: 945-959.

Pugh, T., O. Fouet, A. M. Risterucci, P. Brottier, M. Abouladze, C. Deletrez, B. Courtois, D. Clement, P. LARMAnde, J. A. K. NGoran and C. LANAud (2004): A new cacao linkage map based on codominant markers: development and integration of 201 new microsatellite markers Theor. Appl Genet 108: 1151-1161.

Purseglove, J.W. (1974): Tropical crops, dicotyledons. John Wiley \& Sons, New York.

Quenollle, M. (1956): Notes on bias in estimation. Biometrika 43: 253-260.

RICE, W. R. (1989): Analyzing tables of statistical tests. Evolution 43: 223-225.

Rice, R. A. and R. Greenberg (2000): Cacao cultivation and the conservation of biological diversity. Ambio 29(3): $167-173$.

Saunders, J. A., S. Mischke, E. A. Leamy and A. A. HEMEIDA (2004): Selection of international molecular standard for DNA fingerprinting. Theor. Appl. Genet. 110: 41-47.

Schnell, R. J., C. T. Olano, J. S. Brown, A. W. Meerow, C. Cervantes-Martinez, C. Nagai and J.-C. Motamayor (2005): Retrospective determination of the parental population of superior cacao (Theobroma cacao L.) seedlings and association of microsatellite alleles with productivity. J. Amer. Soc. Hort. Sci. 130: 181-190.

Sereno, M., P. P. Albuquerque, R. Vencovsky and A. FiguerA (2006): Genetic diversity and natural population structure of cacao, Theobroma cacao L. from the Brazilian Amazon evaluated by microsatellite markers. Conservation Genetics 7: 13-24.

Sweigart, A., K. Karoly, A. Jones and J. H. Willis (1999): The distribution of individual inbreeding coefficients and an pairwise relatedness in a population of Mimulus guttatus. Heredity 83: 625-632.

Toxopeus, H. (1964): $\mathrm{F}_{3}$ Amazon cacao in Nigeria. Rep. Cacao Res. Inst. Nigeria, 1963/64, pp.13-22.

WeIR, B. S. and C. C. CoCKERHAM (1984): Estimating F-statistics for the analysis of population structure. Evolution 38: 1358-1370.

WRIGHT, S. (1965): The interpretation of genetic structure by F-statistics with special regard to systems of mating. Evolution 19: 355.

Zhang, D., E. Arevalo, B. Mischke, L. Zuniga and A. BarRETO (2006a): Genetic diversity and population structure of cocoa, Theobroma cacao L. in the Hullaga and Ucayali valleys of Peru. Annals of Botany 98: 647-655.

Zhang, D., E. Arevalo, S. Mischke, R. Goenaga, A. A. HEMEIDA and J. A. SAUNDERS (2006b): Accuracy and reliability of high-throughput microsatellite genotyping for cacao clone identification. Crop Science 46: 2084-2092.

ZHANG, D., M. Boccara, L. Motilal, D. R. Butler, P. Umaharan, S. Mischke and L. Meinhardt (2008): Microsatellite variation and population structure in the "refractario" cacao of Equador. Conserv Genet 9: 327-337.

Zhang, D., S. Mischke, E. S. Johnson, W. Phillips-Mora and L. Meinhardt (2009): Molecular characterization of an International cocoa collection using microsatellite markers. Tree Genetics \& Genomes 5: 1-10.

\title{
Cross-amplification and Characterization of Polymorphic Microsatellite Markers From Acacia (Senegalia) mellifera and Acacia brevispica to Acacia senegal (L.) Willd.
}

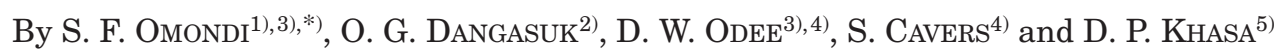

(Received $6^{\text {th }}$ May 2009)

\footnotetext{
1) Department of Forestry and Wood Science, Moi University, P.O Box 1125 Eldoret, Kenya.

2) Department of Biological sciences, Moi University, P.O. Box 1125 Eldoret, Kenya.

3) Kenya Forestry Research Institute, P.O. Box 20412-00200 Nairobi, Kenya

4) Centre for Ecology and Hydrology, Bush Estate, Penicuik, Midlothian, EH26 0QB, UK.

5) Centre for Forest Research and Canada Research Chair in Forest and Environmental Genomics, Université Laval, SainteFoy, Québec, Canada G1V 0A6.

*) Author of correspondence: STEPHEN F. OMONDI. E-Mail: stephenf.omondi@gmail.com
}

\begin{abstract}
Seven polymorphic microsatellite markers isolated from Acacia brevispica and Acacia mellifera were successfully cross-amplified in Acacia senegal. The loci were surveyed for polymorphism using 30 samples. Allelic diversity ranged from 4 (Ame02, $A b 06$ and Ab18) to 13 (Ab26) per locus. The expected heterozygosity $\left(\mathrm{H}_{\mathrm{F}}\right)$ ranged from 0.543 (Ame02) to 0.868 (Ab26) while observed heterozygosity $\left(\mathrm{H}_{\mathrm{O}}\right)$ ranged from 0.516 (Ame05) to 0.800 (Ame03). Cross-amplification of these loci represents a potential source of co-dominant markers and will be useful in the study of genetic diversity, structure,
\end{abstract}

